\title{
NATURAL ENEMIES ATTACKING THE MEALY APHID, HYALOPTERUS PRUNI (GEOFFROY) IN PEACH ORCHARD AT ISMAILIA GOVERNORATE, EGYPT
}

\author{
SALEH, A.A.A. ${ }^{1}$, SH. A.M. ALI ${ }^{2}$ and NADIA E. MOHAMED ${ }^{1}$
}

1. Biological Control Research Dept., Plant Prot. Res. Institute, ARC, Dokki, Giza, Egypt

2. Piercing \& Sucking Insect Research Dept. Plant Prot. Res. Institute, ARC, Dokki, Giza, Egypt

(Manuscript received 8 March 2012)

\begin{abstract}
The present investigation was carried out at Ismailia Governorate during 2010 and 2011 seasons to evaluate the seasonal activity of the parasitoids and predators associated with the mealy aphid Hyalopterus pruni population.

During the study two parasitoid species belonging to Aphidius colemani Viereck and Aphidius picipes (Nees) and six predator species, Chrysoperla carnea Steph., Coccinella undecimpunctata L. Aphidoletes aphidimyza Rond., Syrphus corollae F. Cydonia vicinia nilotica Muls. and Scymnus interruptus Goeze. were recorded.

The highest percentage of parasitism by the two parasitoids were recorded on the half of May (48.11\%), during 2010, while in the second season 2011 was recorded in the last week of May (51.56\%) with on average percentage of parasitism 20.77 and $18.03 \%$ during the two successive seasons respectively.

Laboratory experiments were carried out to study some biological aspects of the main natural enemies associated with the mealy aphid. The obtained results indicated that the developmental period as well as adult longevity of the parasitoid $A$. colemani was affected by temperature and food. However, the developmental period decrease as temperature increase. Total developmental periods of $A$. colemani ranged between 9.2-37.37 days, also the longevity was affected by temperature and food for $A$. colemani. Studying the behavior of the same parasitoid at varying host densities showed a decrease of leaf - arrival times and host arrival times with increasing of host density but number of stings and number of mummies increased with increase of host density. Statistical analysis showed that temperature and relative humidity were significant with some insects and insignificant with the others. Key words: Hyalopterus pruni, Predators, Parasitoids , Biology.
\end{abstract}

\section{INTRODUCTION}

Aphid insects are among the most injurious pests attacking fruit trees. Damage caused by aphids is mainly due to feeding on the plant - sap causing direct injury to the trees. Aphids are also known to transmit virus diseases to the plants (Ismail et al., 1991). 
The use of insecticides in controlling aphids, generally, leads to many problems not only increasing resistant strains of aphids to these chemical substances, but also in induction of pollution to man and beneficial insects such as bees and other pollinators, insect parasitoids and predators (El-Maghraby , 1993).

The relationships between aphids and their natural enemies have drawn the attention of many investigators in Egypt (El-Maghraby 1993 and Ali , 2008).

Therefore the aim of this investigation is to study :

1.The seasonal abundance of aphid and their parasitoids and predators on peach trees in Ismailia Governorate, Egypt.

2.Biology and behavior of Aphidius colemani on peach trees .

3.Effect of certain climatic factors on the population density of aphid and their associated predators and parasitoids at Ismailia Governorate, Egypt.

\section{MATERIALS AND METHODS}

\section{Estimation of the role of natural enemies on $H$. pruni population in the field:}

This work was carried out at Ismailia Governorate , Egypt during 2010 and 2011 seasons. An area of feddan was selected at Ismailia Governorate. This area received all normal recommended agricultural practices, except absence of any chemical insecticidal treatment. Sampling started in the first week of March. Inspections continued till the first week of July and last week of June in the two seasons respectively, for peach trees. Weekly sampling of 60 infesting leaves (12 leaves $\times 5$ trees) were randomly collected kept in paper bag and transferred to the laboratory. The numbers of Hyalopterus pruni (nymphs and adults) were recorded for each sample. Meanwhile, the numbers of predators associated with aphid were also recorded. To estimation of parasitism rates, last aphid individuals were fed on their host plant and kept in Petri dishes (50 aphid individuals / Petri- dish) until formation of mummies. The mummies were isolated and kept in small glass tubes until emergence of adult parasitoids. Adult emerged from mummies, were classified, counted and their percentages were also calculated. Emerged parasitoids were mounted and identified at the Biological Control Department, ARC, Giza, Egypt. Percentage of parasitism was calculated as monthly means according to Ferrell and Stufkens (1990). Daily records of both minimum and maximum temperatures along with relative humidity throughout the two seasons were obtained from the Agrometereological Station at Ismailia region. Correlation between weekly average 
numbers of $H$. pruni, (parasitoids \& predators) and corresponding weekly means of temperature and relative humidity were estimated.

\section{Biology:}

\subsection{Life cycle of Aphidius colemani on $H$. pruni;}

A laboratory culture of the aphid, $H$. pruni was maintained under laboratory conditions. The aphid was reared on caged young seedling of its host (peach seedling) or on detached young leaves set flat on the bottom of clear plastic Jar. The Jar inverted so that the aphids fed in a natural position on the under surface of the leaf and change the leaf daily. A laboratory culture of the parasitoid, A. colemani started with mummies obtained from the field - Mummified aphid were placed singly in small glass tubes until the emergence of adult parasitoids which were fed on sugar solution (concentration 50\%). To determine the durations of different immature stages of the parasitoid on the nymphs of $H$. pruni, nymphs were confined with the parasitoid for 2-6 hours. Thirty nymphs of parasitized host aphids were daily dissected to determine the developmental rate of different immature stages of the parasitoid.

\subsection{Effect of temperature and food supply on the adult longevity of the parasitoid A.colemani :}

Forty mated females and forty males of the parasitoid species were obtained from the laboratory culture (12 hours) after adult emergence. Each individual was confined in a small glass tube $(9 \times 2 \mathrm{~cm})$. The females and males of the parasitoids were divided into four groups, each of ten replicates, group (I) starved females and males, group (II) both sexes were supplied daily with $10 \%$ sugar solution and kept at room temperature $\left(23^{\circ} \mathrm{C}\right)$, group (III) adult female and males also starved and group (IV) was supplied daily with $10 \%$ sugar solution but kept in refrigerator at $9^{\circ} \mathrm{C}$.

\subsection{Behavior of the parasitoid A. colemani at varying host densities:}

Aphidius colemani on varying host densities 30, 60, 90 , 120 and 150 nymphs of the aphid H. pruni (mostly $3^{\text {rd }}$ instars) on leaves of peach plant, were placed separately in Petri- dishes lined with moistened filter paper. Freshly emerged to $12 \mathrm{~h}$. old molted parasitoid females, fully fed with $50 \%$ honey solution were gently introduced into each Petri - dish. The Petri dishes were covered with glass plates.

The behavior of the parasitoid was observed for $30 \mathrm{~min}$ and recorded, 1 - the period between introduction of the female and her first contact with the food plant, leaf (leaf - arrival time) and host (host- arrival time), 2- number of oviposition (No. of stings) and 3-No. of results mummies. The experiment was performed five times. All experiments were statistically analyzed using ANOVA, and the means were separated using Dancan's Multiple Range Test (CoHort Software, 2004). 


\subsection{Effect of certain climatic factors on the population density of aphid and their associated predators and parasitoids at Ismailia Governorate , Egypt:}

Daily records of minimum and maximum temperature along with relative humidities were obtained from the Agrometeorological station at Ismailia region during 2010 and 2011. The relationship between the biweekly total number of aphid individuals and the corresponding biweekly means of minimum and maximum temperatures and relative humidity were recorded. The simple correlation and multiple partial regression were calculated according to (Co Hort Software, 2004).

\section{RESULTS AND DISCUSSION}

\section{a. Seasonal abundance of $\boldsymbol{H}$. pruni illustrated population in response to} their associated predators:

The data in Figs. $(1 \& 2)$ showed that the population of $H$. pruni and associated predators throughout the two seasons of study.

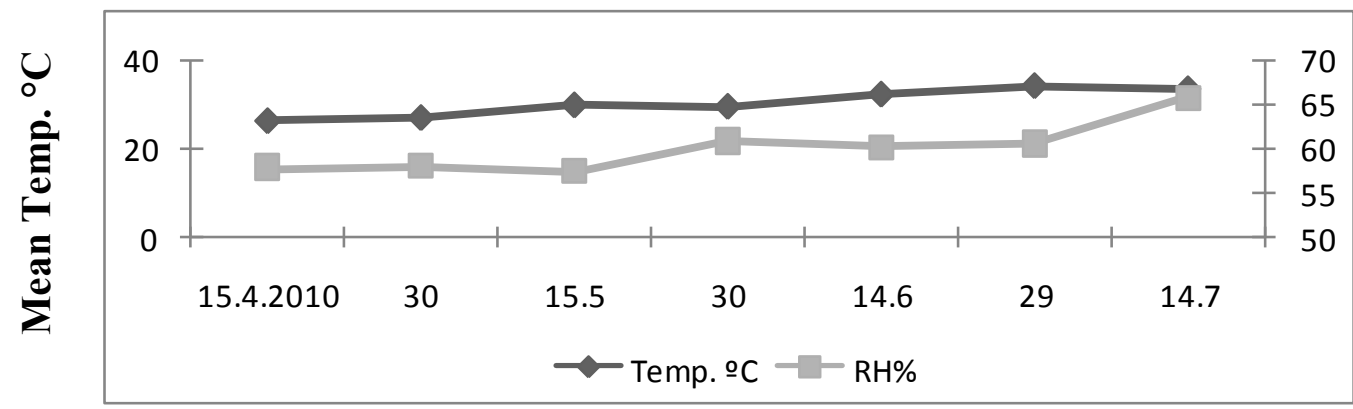



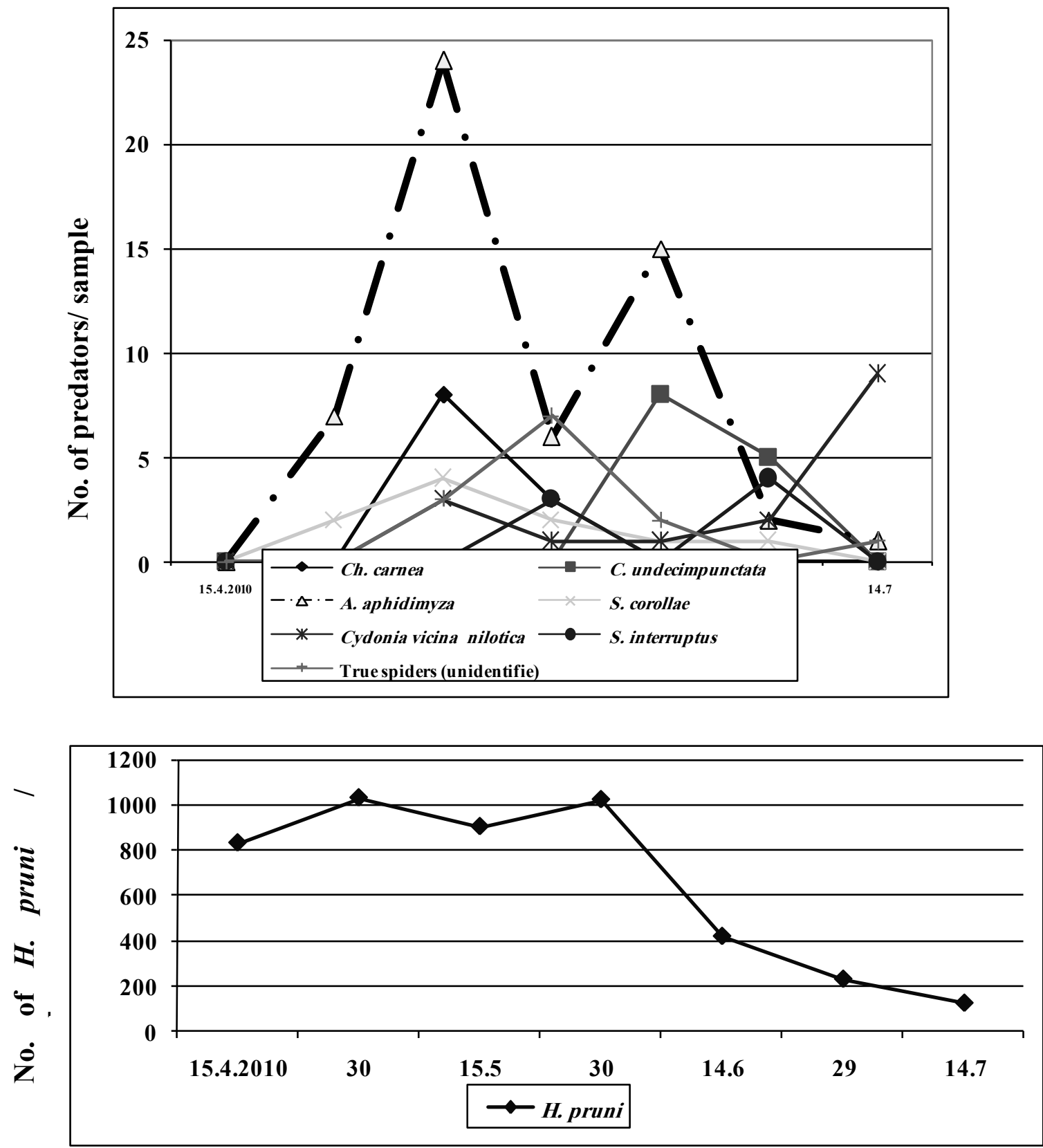

Biweekly date of sample

Fig. 1. The relation between $H$. pruni and associated predators population during 2010 season. 

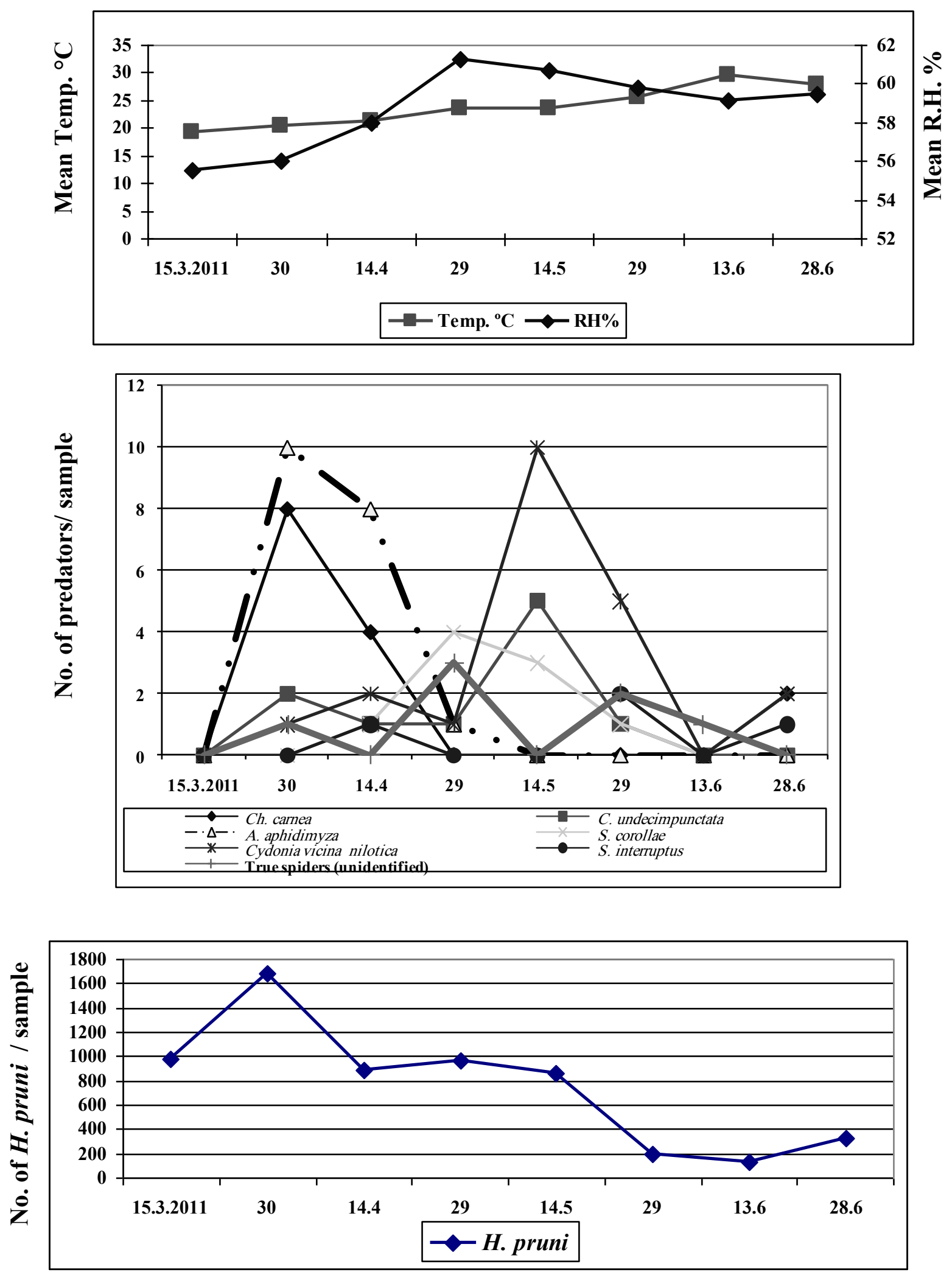

Biweekly date of sample

Fig. 2. The relation between $H$. pruni and associated predators population during 2011 season. 
The aphid population reach its maximum biweekly total numbers in April (1031 individuals /60 leaves), in 2010 and (1687 individuals / 60 leaves) in March during 2011. The pest population decreased sharply at the end of each season (124 \& 134 individuals) in July 2010 and June 2011 . The seasonal mean numbers of $H$. pruni (per 60 leaves) were , 651.86 (124-1031) and 754.75 (134-1687) individuals, in seasons, 2010 and 2011, respectively, showing a total mean of 703.31 (124-1687) individuals/ 60 leaves for the two seasons (Figs. 1 and 2).

The population density and life cycle of $H$. pruni was investigated in Egypt, by some other (El-Kady et al., 1970). On the other hand Ibrahim and Afifi (1994) showed that the weekly mean number of healthy and parasitized aphid/ leaf appeared on the peach trees from February to October 1993 . Similarly, the peach aphid H. pruni was recorded as major pest attacking peach trees, three peaks of activity in 2001, two peaks in 2002 in Egypt by Ismail et al., 1986 \& 1991 and Ali 2008.

\section{b. Seasonal abundance of aphidophagous species and aphid, $H$. pruni population:}

Table (1) show the numbers of common predators associated with $H$. pruni on peach trees. The insect predators belonged to four insect orders, larvae of Ch. carnea Steph. (Neuroptera: Chrysopidae), adults \& larvae of C. undecimpunctata L., C. vicina nilotica, S. interruptus (Coleoptera: Coccinellidae), adults \& larvae of Aphidoletes aphidimyza (Diptera: Cecidomyiidae) and Syrphus corollae (Diptera: Syrphidae). True spiders (unidentified species), were also recorded during the study. The total numbers and occurrence percentages of these species were Ch. carnea (11 individuals $=8.80 \%$ and 14 individuals $=16.28 \%), C$. undecimpunctata (13 individuals $=10.40 \%)$ and 10 individuals $=11.63 \%)$, . aphidimyza $(55$ individuals $=$ $44.0 \%$ and 19 individuals $=22.09 \%$, S. corollae $(10$ individuals $=8.0 \%$ and 11 individuals $=12.79 \%)$ C. vicina nilotica $(16$ individuals $=12.8 \%$ and 21 individuals $=$ $24.42 \%$ ) and $S$. interruptus ( 7 individuals $=5.60 \%$ and 4 individuals $=4.65 \%$ ). While true spider ( 13 individuals $=10.4 \%$ ) and 7 individuals $=8.14 \%$ ) in the two seasons, respectively (Table 1 ). 
Table 1. Total collected numbers (A) and occurrence percentage (B) of predaceous species associated with $H$. pruni during 2010 and 2011 seasons.

\begin{tabular}{|l|c|c|c|c|}
\hline \multirow{2}{*}{ Insect predators } & \multicolumn{2}{c|}{2010} & \multicolumn{2}{c|}{2011} \\
\cline { 2 - 5 } & A & B & A & B \\
\hline Aphidoletes aphidimyza Rond. & 55 & 44.5 & 19 & 22.09 \\
\hline Cydonia vicina nilotica Muls. & 16 & 12.8 & 21 & 24.42 \\
\hline Coccinella undecimpunctata L. & 13 & 10.4 & 10 & 11.63 \\
\hline True spiders & 13 & 10.4 & 7 & 8.14 \\
\hline Chrysoperla carnea (Steph.) & 11 & 8.8 & 14 & 16.28 \\
\hline Syrphus corollae F. & 10 & 8.0 & 11 & 12.79 \\
\hline Scymnus interruptus Goeze. & 7 & 5.6 & 4 & 4.65 \\
\hline Total & 125 & 100 & 86 & 100 \\
\hline
\end{tabular}

(A) Total number predators

(B) \% Occurrence

Al-Allan et al. (2004) stated that, the aphidophagous coccinellids were of particular importance and usually play an important natural role in regulating and /or suppressing the populations of their potential preys principally aphid species. Boraei et al. (2005) found that, chrysopid and coccinellid beetles were among the common predators in most Egyptian field crops.

\section{Rate of parasitization:}

Table (2) show that two primary parasitoid species, Aphidius colemani Vier and Aphidius picipes (Nees) were recorded, the percentages of parasitism ranged from $5.65 \%$ to $48.11 \%$ during the first

season and from $2.90 \%$ to $51.56 \%$ during the second season. In the first season 2010, the percentage of parasitisim started by $7.81 \%$ in the second week of April and it increased until reach the peak of $48.11 \%$ in the second week of May. In the second season 2011 , the percentage of parasitism started by $2.90 \%$ in the fourth week of March and it increased until reached the peak of $51.56 \%$ in the fourth week of May.

Total means of parasitism rate of $A$. colemani and $A$. picipes together were 20.77 and $18.03 \%$ during 2010 and 2011 seasons, respectively. The primary parasitoid $A$. colemani was the most dominant species with mean relative densities (74.83 and $79.77 \%$ ) during the two seasons, respectively. Meanwhile, the mean relative densities of primary parasitoid. $A$. picipes were 10.88 and $7.73 \%$, respectively (Table 2). 
Table 2. Percentage of parasitism on H. pruni on peach trees during 2010 and 2011 seasons at Ismailia Governorate, Egypt.

\begin{tabular}{|c|c|c|c|c|c|c|c|c|c|c|c|c|c|}
\hline \multirow{2}{*}{$\begin{array}{c}\text { Sampling } \\
\text { dates }\end{array}$} & \multirow{2}{*}{$\begin{array}{c}\text { No. of } \\
\text { dissected } \\
\text { aphid }\end{array}$} & \multicolumn{3}{|c|}{ No. of parasitoid aphids } & \multirow{2}{*}{$\begin{array}{c}\text { Total } \\
\text { parasitism } \\
\% \\
\end{array}$} & \multicolumn{4}{|c|}{ Emerged parasitoids } & \multirow[t]{2}{*}{ Total } & \multicolumn{3}{|c|}{ Weather factors } \\
\hline & & A & B & Total & & No. & $\mathrm{RD} \%$ & No. & $\mathrm{RD} \%$ & & Max. ${ }^{\circ} \mathrm{C}$ & $\operatorname{Min} .{ }^{\circ} \mathrm{C}$ & Mean R.H \\
\hline 15.4 .2010 & 832 & 39 & 26 & 65 & 7.81 & 46 & 100 & 0 & 0 & 46 & 32.1 & 20.4 & 57.8 \\
\hline 30 & 1031 & 163 & 124 & 287 & 28.05 & 187 & 90.34 & 20 & 9.66 & 207 & 32.7 & 21.2 & 58.0 \\
\hline 15.5 & 904 & 301 & 195 & 496 & 48.11 & 336 & 75.51 & 109 & 24.49 & 445 & 36.4 & 23.13 & 57.4 \\
\hline 30 & 1023 & 205 & 129 & 334 & 36.95 & 213 & 75.27 & 70 & 24.73 & 283 & 34.7 & 24.19 & 60.8 \\
\hline 14.6 & 419 & 41 & 38 & 79 & 18.85 & 43 & 82.69 & 9 & 17.31 & 52 & 37.6 & 26.73 & 60.13 \\
\hline 29 & 230 & 2 & 5 & 13 & 5.65 & 10 & 100 & 0 & 0 & 10 & 39.7 & 28.4 & 60.5 \\
\hline 14.7 .2010 & 124 & 0 & 0 & 0 & 0 & 0 & 0 & 0 & 0 & 0 & 37.4 & 29.3 & 65.7 \\
\hline Mean & 651.86 & 107.28 & 73.86 & 182.0 & 20.77 & 119.28 & 74.83 & 29.17 & 10.88 & 149.0 & & & \\
\hline 15.3 .2011 & 983 & 0 & 0 & 0 & 0 & 0 & 0 & 0 & 0 & 0 & 23.4 & 16.2 & 55.5 \\
\hline 30 & 1687 & 0 & 49 & 49 & 2.90 & 34 & 100 & 0 & 0 & 34 & 24.8 & 16.2 & 56.0 \\
\hline 14.4 & 893 & 59 & 45 & 104 & 11.65 & 68 & 81.93 & 15 & 18.07 & 83 & 26.4 & 15.9 & 58.0 \\
\hline 29 & 964 & 90 & 66 & 156 & 16.18 & 108 & 81.82 & 24 & 18.18 & 132 & 29.5 & 17.6 & 61.3 \\
\hline 14.5 & 862 & 149 & 139 & 288 & 33.41 & 209 & 90.87 & 21 & 9.13 & 230 & 29.4 & 17.6 & 60.7 \\
\hline 29.5 & 192 & 52 & 47 & 99 & 51.56 & 66 & 83.54 & 13 & 16.46 & 79 & 31.6 & 19.3 & 59.8 \\
\hline 13.6 & 134 & 19 & 13 & 32 & 23.88 & 23 & 100 & 0 & 0 & 23 & 35.5 & 23.7 & 59.1 \\
\hline 28.6.2011 & 323 & 9 & 6 & 15 & 4.64 & 11 & 100 & 0 & 0 & 11 & 34.5 & 21.3 & 59.5 \\
\hline Mean & 757.75 & 47.25 & 45.62 & 92.87 & 18.03 & 64.87 & 79.77 & 9.12 & 7.73 & 74.0 & & & \\
\hline
\end{tabular}

$A=$ No. of mummified host counted at the date of inspection

$B=$ No. of mummified host counted during the laboratory rearing

$\mathrm{N}=$ Number

$\mathrm{RD}=$ Relative density 
The present results agree with those of Ibrahim and Afifi (1994) and Ali (2008) who recorded $A$. colemani and $A$. picipes as parasitoids on mealy aphid $H$. pruni in Egypt. Also, Ibrahim and Afifi (1994) showed that percentage of parasitism reached 32.4 and $29.3 \%$ respectively.

\section{Biological studies:}

\subsection{Life cycle of A. colemani on H. pruni :}

Results in Table (3) showed that the temperature played an important role on the developmental period of $A$. colemani on $H$. pruni. Generally, developmental periods of different stages of parasitoid $A$. colemani shortened as the temperature increased from 9 to $30^{\circ} \mathrm{C}$. At $9^{\circ} \mathrm{C}$ the incubation period of egg averaged 8.08 days. Larval period averaged 13.61 days and pupal stage recorded 15.68 days. The total developmental period of the parasitoid $A$. colemani lasted 37.37 days.

At $23^{\circ} \mathrm{C}$, the incubation period of eggs, larval and pupal stages of $A$. colemani averaged of 2.76, 5.08 and 4.94 days, respectively. The total averages for development period of the parasitoid recorded 12.78 days. At $30^{\circ} \mathrm{C}$, the incubation period of eggs, larval and pupal stages of the same parasitoid averaged of 2.33, 3.34 and 3.53 days, respectively. The total averages for development period of the parasitoid recorded 9.2 days. However, Ibrahim (1987) in Egypt, investigated the developmental period of $A$. uzbekistanicus and found that the total development period of the parasite increased as temperature decreased. Also, Saleh (2000) showed that the total developmental period of Aphidius sp. lasted for 10-15 days with an average of $13.85 \pm 0.29$ (at $21.7^{\circ} \mathrm{C}$ ) when reared on $S$. avenae. 
Table 3. Developmental periods of immature stages and longevity adults (in days) of the parasitoid Aphidius colemani Viereck on Hyalopterus pruni infesting peach trees at 9,23 and $30^{\circ} \mathrm{C}$ at $65+5 \%$

\begin{tabular}{ccccc}
\hline Temp ${ }^{\circ} \mathrm{C}$ & Stage & $\begin{array}{c}\text { Duration mean } \pm \\
\text { S.E }\end{array}$ & $\begin{array}{c}\text { Longevity } \\
\text { female }\end{array}$ & Male \\
\hline $9^{\circ} \mathrm{C}$ & Egg & $8.08^{\mathrm{a}}+0.98$ & $9.82 \pm 0.39$ & $6.73 \pm 0.42$ \\
& Larva & $13.6^{\mathrm{a}}+0.78$ & & \\
& Pupa & $15.68^{\mathrm{a}} \pm 0.63$ & & \\
& Total (egg - adult) & $37.37^{\mathrm{a}}+0.34$ & & \\
\hline $23^{\circ} \mathrm{C}$ & Egg & $2.76^{\mathrm{b}}+0.26$ & $3.95 \pm 0.53$ & $2.34 \pm 0.49$ \\
& Larva & $5.08^{\mathrm{b}}+0.54$ & & \\
& Pupa & $4.94^{\mathrm{b}}+0.38$ & & \\
& Total (egg - adult) & $12.78^{\mathrm{b}}+0.71$ & & \\
\hline $30^{\circ} \mathrm{C}$ & Egg & $2.33^{\mathrm{b}}+0.15$ & $2.69 \pm 0.61$ & $1.72 \pm 0.35$ \\
& Larva & $3.34^{\mathrm{c}}+0.26$ & & \\
& Pupa & $3.53^{\mathrm{c}}+0.19$ & & \\
& Total (egg - adult) & $9.20^{\mathrm{c}}+0.32$ & & \\
\hline
\end{tabular}

\subsection{Effect of temperature and food supply on longevity of A. colemani:}

As shown in Table (4), the adult longevity of starved females was longer than that of starved males when both were kept at room temperature of $23^{\circ} \mathrm{C}$ (Group I). Also, the female lived longer than male when fed at room temperature (Group II), meanwhile, starved or fed females lived, longer than males kept in the refrigerator at $9^{\circ} \mathrm{C}$ (Group III) .On the other hand, Stary (1970) reported that the adult life span of parasitoids were affected by many factors such as temperature, humidity, food and presence or absence of hosts. The obtained results are generally in agreement with those obtained by (Saleh, $2000 \& 2008$ ).

Table 4. Effect of temperature and food supply on the longevity of $A$. colemani emerged from $H$. pruni.

\begin{tabular}{|c|c|c|c|c|c|c|}
\hline \multirow[b]{2}{*}{ Group } & \multirow[b]{2}{*}{ Treatment } & \multirow{2}{*}{$\begin{array}{c}\text { Temp. } \\
{ }^{\circ} \mathrm{C}\end{array}$} & \multicolumn{2}{|c|}{ Adult longevity in days } & \multirow{2}{*}{$\begin{array}{l}\text { Male } \\
\text { Range }\end{array}$} & \multirow[b]{2}{*}{ Mean $\pm S E$} \\
\hline & & & $\begin{array}{l}\text { Female } \\
\text { Range }\end{array}$ & Mean \pm S.E & & \\
\hline I & - & 23 & $2-5$ & $3.84^{\mathrm{d}} \pm 0.34$ & $1-3$ & $2.31^{\mathrm{d}} \pm 0.21$ \\
\hline II & + & 23 & $4-7$ & $6.09^{c} \pm 0.29$ & $2-5$ & $3.53^{\mathrm{C}} \pm 0.23$ \\
\hline III & - & 9 & $6-11$ & $9.61^{\mathrm{b}} \pm 0.47$ & $4-7$ & $6.27^{\mathrm{b}} \pm 0.27$ \\
\hline IV & + & 9 & $9-17$ & $13.35^{\mathrm{a}} \pm 0.62$ & $4-10$ & $8.54^{\mathrm{a}} \pm 0.46$ \\
\hline
\end{tabular}

\subsection{Behavior of the parasitoid A. colemani at varying host densities:}

As shown in Table (5), leaf - arrival and host- arrival times (host - searching time are measures of the attractive potency of the semio- chemicals emitted by the 
food plants and the hosts (Brown et al. 1970). Leaf - arrival time and host arrival time decreased with increasing host density. The increased number of oviposition and number of mummies with increase of host density might be due to increased concentration of the kairomones which enhance the activity of the parasitoid (Saleh, 2004) and increased surface area of contact of the hosts (Saleh, 2008).

Table 5. Behavior of the parasitoid Aphidius colemani on peach at varying Hyalopterus pruni densities

\begin{tabular}{cccccc}
\hline $\begin{array}{c}\text { Host } \\
\text { density }\end{array}$ & $\begin{array}{c}\text { Leaf -arrival } \\
\text { time (min.) }\end{array}$ & $\begin{array}{c}\text { Host -arrival } \\
\text { time (min.) }\end{array}$ & $\begin{array}{c}\text { First sting } \\
\text { time (min.) }\end{array}$ & $\begin{array}{c}\text { No. of sting } \\
\text { (oviposition) }\end{array}$ & $\begin{array}{c}\text { No. of } \\
\text { mummies }\end{array}$ \\
\hline 30 & $8.41^{\mathrm{a}} \pm 0.28$ & $8.47^{\mathrm{a}} \pm 0.23$ & $7.99^{\mathrm{e}} \pm 0.53$ & $8.0^{\mathrm{e}} \pm 0.41$ & $5.0^{\mathrm{d}} \pm 0.40$ \\
60 & $5.93^{\mathrm{b}} \pm 0.41$ & $6.35^{\mathrm{b}} \pm 0.29$ & $14.63^{\mathrm{d}} \pm 0.46$ & $36.5^{\mathrm{d}} \pm 1.32$ & $12.25^{\mathrm{c}} \pm 1.11$ \\
90 & $2.34^{\mathrm{c}} \pm 0.21$ & $3.85^{\mathrm{c}} \pm 0.31$ & $16.99^{\mathrm{c}} \pm 0.53$ & $46.75^{\mathrm{c}} \pm 1.55$ & $13.50^{\mathrm{bc}} \pm 0.65$ \\
120 & $1.90^{\mathrm{c}} \pm 0.09$ & $2.10^{\mathrm{d}} \pm 0.11$ & $20.32^{\mathrm{b}} \pm 0.38$ & $65.25^{\mathrm{b}} \pm 2.29$ & $15.75^{\mathrm{b}} \pm 0.85$ \\
150 & $1.05^{\mathrm{d}} \pm 0.23$ & $1.09^{\mathrm{e}} \pm 0.20$ & $23.19^{\mathrm{g}} \pm 0.30$ & $76.25^{\mathrm{a}} \pm 3.04$ & $20.25^{\mathrm{a}} \pm 0.86$ \\
F. test & $* *$ & $* *$ & $* *$ & $* *$ & $* *$ \\
L.S.D.0.05 & 0.8022 & 0.7018 & 1.3554 & 5.8405 & 2.4380 \\
\hline
\end{tabular}

2.4. Effect of certain climatic factors on the population density of aphid and their associated predators and parasitoids at Ismailia Governorate, Egypt.

Results in Table (6) showed the values of correlation coefficient of the relation among temperature, relative humidity and the population density of $H$. pruni, some predators and parasitoids during 2010 and 2011. Maximum temperature parameters indicated highly negative significant effect on the population density Aphidius colemani and significant negative effect on the population density of $H$. pruni, A. aphidimyza, S. corollae and A. picipes, while, positive significant effect on the population density of $C$. vicina nilotica and S. interruptus in the first season 2010. Also maximum temperature indicated negative significant effect on $A$. aphidimyza and showed positive effect on the population density of $S$. interruptus. On the other hand minimum 
Table 6. Simple correlation coefficient values between temperature relative humidity and the total numbers of $H$. pruni and some predators and parasitoids in Ismailia region during 2010 and 2011 seasons.

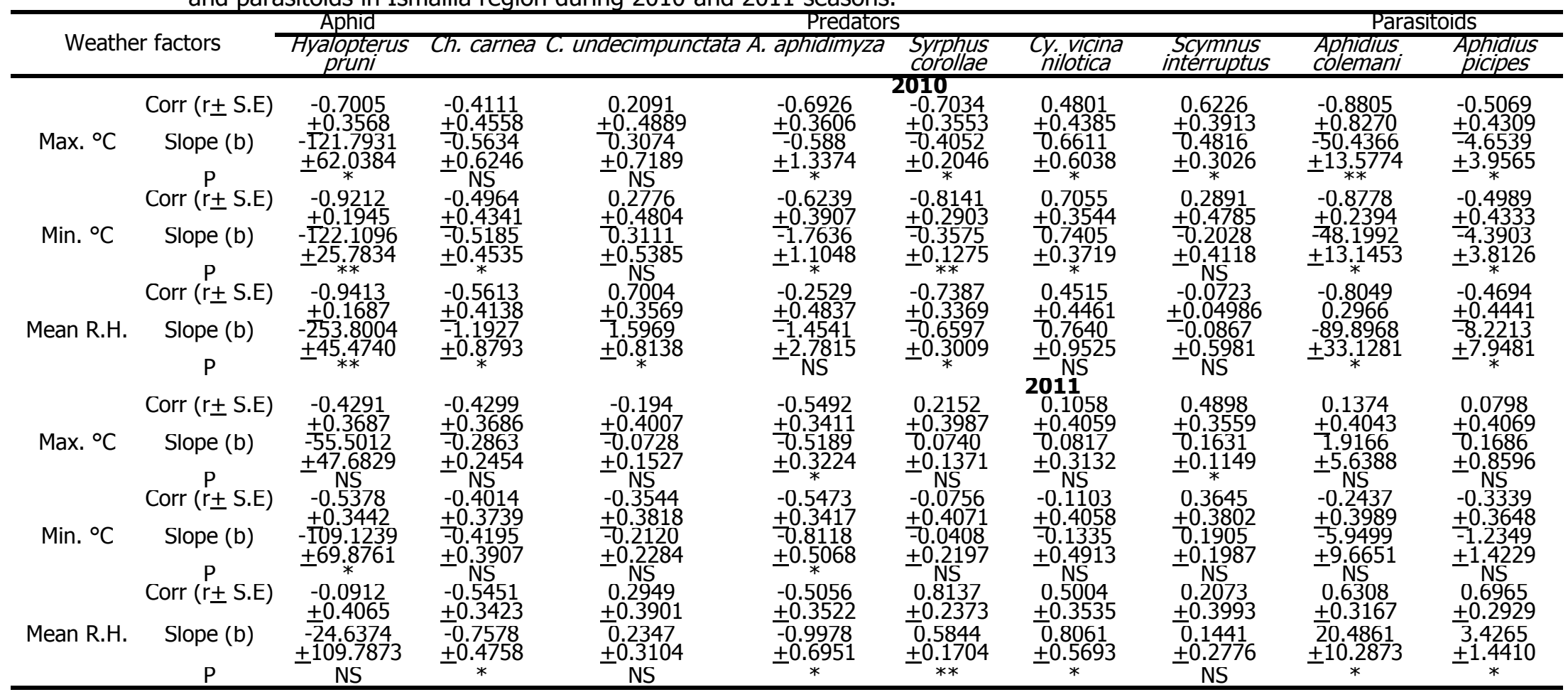


temperature parameters induced highly significant negative correlations, $(-0.9212 * *$ and $-0.8141^{* *}$ ) on the population density of $H$. pruni and $S$. corollae and also negative significant effect on the population density of Ch. carnea, A. aphidimyza , A. colemani and Aphidius picipes but, showed positive significant on the population density of $C$. vicina nilotica in 2010 season, while in 2011 season, the minimum temperature induced negative significant effect $\left(-0.5378^{*}\right.$ and $\left.-0.5473^{*}\right)$ on the population density of $H$. pruni and $A$. aphidimyza respectively. Mean while, the mean relative humidity induced highly significant negative correlations, $\left(-0.9413^{* *}\right)$ on the population density of $H$. pruni in 2010 and showed highly significant positive effect $(0.8137 * *)$ on the population density of $S$. corollae in 2011 . On the other hand, the mean relative humidity indicated significant negative correlation $(-0.5613 *,-0.7387 *,-0.8049 *$ and $-0.4694 *)$ on the population density of Ch. carnea, S. corollae, A. colemani and A. picipes and showed significant positive correlation $\left(0.7004^{*}\right)$ on the population density of $C$. undecimpunctata in 2010, mean while in the second season 2011, the mean relative humidity showed significant positive correlation $\left(0.5004^{*}, 0.6308^{*}\right.$ and $\left.0.6965^{*}\right)$ on the population density of $C$. vicina nilotica, $A$. colemani and $A$. picipes, while, induced significant negative correlation $\left(-0.5451^{*}\right.$ and $\left.-0.5056 *\right)$ on the population density of Ch. carnea and $A$. aphidimyza.

Results in Table (7) showed the values of the correlation coefficient of relation between some parasitoids and predators and the population density of $H$. pruni during the two seasons. The parasitoid, $A$. colemani showed highly positive significant $\left(0.8646^{* *}\right)$ and showed positive significant on the population density of $A$. picipes in 2010 season. Also, the two predator Ch. carnea and S. corollae showed positive significant correlation and induced negative significant correlation on the population density of $C$. undecimpunctata and C. vicina nilotica in 2010 seasons. Meanwhile, the two predators, Ch. carnea and $C$. undecimpunctata showed positive significant effect on the population density of $H$. pruni in the second season 2011. Data in Table (8) showed the numerical relation among temperature, relative humidity and population density of $H$. pruni, some predators and parasitoids during two seasons at Ismailia region. 
Table 7. Correlation coefficient between $H$. pruni and some parasitoids and predators in Ismailia region during 2010 and 2011 seasons.

\begin{tabular}{|c|c|c|c|c|c|c|c|}
\hline \multirow[b]{2}{*}{ Species } & \multirow[b]{2}{*}{ Natural enemies } & \multicolumn{3}{|c|}{2010} & \multicolumn{3}{|c|}{2011} \\
\hline & & $\begin{array}{c}\text { Corr }(r) \pm \\
\text { S.E. }\end{array}$ & Slop (b) & $P$ & $\begin{array}{c}\text { Corr }(r) \pm \\
\text { S.E. }\end{array}$ & Slop (b) & $P$ \\
\hline \multirow{14}{*}{ 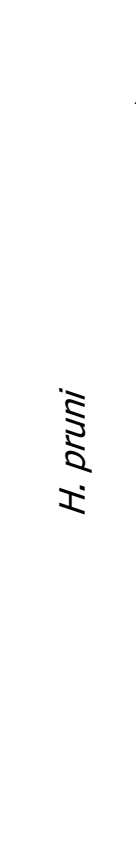 } & & \multicolumn{6}{|c|}{ Parasitoids } \\
\hline & Aphidius colemani & 0.8646 & 0.3581 & $* *$ & 0.3319 & 0.0404 & NS \\
\hline & & \pm 0.2513 & \pm 0.1040 & & \pm 0.3851 & \pm 0.0469 & \\
\hline & \multirow[t]{2}{*}{ A. picipes } & 0.4596 & 0.0305 & $*$ & 0.2541 & 0.0047 & NS \\
\hline & & \pm 0.4447 & \pm 0.2944 & & \pm 0.3948 & \pm 0.0073 & \\
\hline & & \multicolumn{6}{|c|}{ Predators } \\
\hline & Ch. carnea & 0.5162 & 0.0041 & $*$ & 0.7712 & 0.0039 & $*$ \\
\hline & & \pm 0.4282 & \pm 0.0034 & & \pm 0.2599 & \pm 0.0013 & \\
\hline & C. & -0.4979 & -0.0042 & $*$ & 0.4985 & 0.0015 & $*$ \\
\hline & undecimpunctata & \pm 0.4336 & \pm 0.0037 & & \pm 0.3539 & \pm 0.0010 & \\
\hline & \multirow[t]{2}{*}{ S.corollae } & 0.7648 & 0.0025 & $*$ & 0.2065 & 5.4927 & NS \\
\hline & & \pm 0.3222 & \pm 0.0010 & & \pm 0.3994 & \pm 0.0011 & \\
\hline & \multirow{2}{*}{$\begin{array}{c}\text { Cydonia vicina var } \\
\text { nilotica }\end{array}$} & -0.6245 & -0.0049 & $*$ & 0.0853 & 5.0884 & NS \\
\hline & & +0.3897 & \pm 0.0011 & & \pm 0.4068 & \pm 0.0024 & \\
\hline
\end{tabular}

The maximum temperature showed significant positive effect on the population density of $H$. pruni, Ch. carnea , A. aphidimyza, S. corollae and $A$. colemani $\left(\mathrm{R}^{2}=0.6333^{*}, 0.5006 * 0.6665^{*}, 0.4976 *\right.$ and $\left.0.80135^{*}\right)$ respectively in the first season, while it was $\left(R^{2}=0.5318 *, 0.6059 *, 0.6152 *\right.$ and $\left.0.6673 *\right)$ on the population density of $H$. pruni, S. corollae, $A$. colemani and $A$. picipes respectively, in the second season. 
Table 8. Numerical relation between temperature, relative humidity and the total numbers of $H$. pruni and some predators and parasitoids in Ismailia region during 2010 and 2011 seasons.

\begin{tabular}{|c|c|c|c|c|c|c|c|c|c|}
\hline $\begin{array}{l}\text { Weather } \\
\text { factors }\end{array}$ & $\begin{array}{c}H . \\
\text { pruni }\end{array}$ & $\begin{array}{c}\text { Ch. } \\
\text { carnea }\end{array}$ & $\begin{array}{c}\text { C. } \\
\text { undecimpunctata }\end{array}$ & A. aphidimyza & $\begin{array}{c}\text { S. } \\
\text { corollae }\end{array}$ & $\begin{array}{c}\text { Cydonia } \\
\text { vicina nilotica }\end{array}$ & $\begin{array}{l}\text { Scymnus } \\
\text { interruptus }\end{array}$ & $\begin{array}{c}\text { A. } \\
\text { colemani }\end{array}$ & $\begin{array}{c}\text { A. } \\
\text { picipes }\end{array}$ \\
\hline & \multicolumn{9}{|c|}{ Season 2010} \\
\hline Max. Temp & $0.6333^{*}$ & $0.5006 *$ & 0.1911 & $0.6665^{*}$ & $0.4976 *$ & 0.2914 & 0.4003 & $0.8013^{*}$ & 0.2766 \\
\hline Min. Temp. & $0.8493 * *$ & 0.2484 & $0.4933^{*}$ & 0.43036 & $0.6638^{*}$ & $0.7554^{*}$ & 0.3108 & $0.8996 * *$ & 0.2554 \\
\hline \multirow[t]{2}{*}{ Mean R.H. } & $0.6833^{*}$ & 0.3619 & $0.5275^{*}$ & 0.0652 & $0.6107^{*}$ & 0.2344 & 0.0148 & $0.6521^{*}$ & 0.2536 \\
\hline & \multicolumn{9}{|c|}{ Season 2011} \\
\hline Max. Temp & $0.5318^{*}$ & 0.1949 & 0.4079 & 0.3034 & $0.6055^{*}$ & 0.4467 & 0.2399 & $0.6152 *$ & $0.6673 *$ \\
\hline Min. Temp. & 0.3246 & 0.2686 & 0.2025 & $0.4912^{*}$ & 0.4238 & 0.3271 & 0.3906 & 0.2234 & 0.3244 \\
\hline Mean R.H. & 0.0830 & 0.3290 & 0.1607 & 0.2820 & $0.8416 * *$ & 0.2517 & 0.3031 & 0.1869 & $0.5892 *$ \\
\hline
\end{tabular}


On the other hand, the minimum temperature showed highly significant positive effect $\left(\mathrm{R}^{2}=0.8493^{* *}\right.$ and $\left.0.8996^{* *}\right)$ on the population density of $H$. pruni and $A$. colemani and showed significant effect positive in the population density of $C$. undecimpunctata, S. corollae and C. vicina nilotica in 2010 season and also showed significant positive on the population density of $A$. aphidimyza in 2011. Mean while the mean relative humidity showed significant positive effect on the population density of H. pruni, C. undecimpunctata, S. corollae and A. colemani in 2010 season, while showed highly significant positive effect on the population density $S$. corollae $\left(\mathrm{R}^{2}=0.8416^{* *}\right)$ and significant positive effect on the population density of $A$. picipes $\left(R^{2}=0.5892^{*}\right)$ in 2011 season Table (8). The obtain results are generally in agreement with those obtained by (Saleh, 2000 and Ali, 2008).

\section{REFERENCES}

1. Al-Allan, M., M.Al-Basala , A. AL-Monufi and N.Hussen. 2004. Laboratory rearing of Coccinella septempunctata L. (Coleopter: Coccinellidae) . $1^{\text {st }}$ Arab conference of Applied Biological Pest Control, Cairo, Egypt, 5-7 April.

2. Ali, Sh.A.M. 2008. Relationship between aphids and aphidophagous insects in ElKhattara district. Ph. D. Thesis, Fac. of Agric., Zagazig Univ., pp. 191.

3. Boraei, H.A.Y., E.Asmhan , E.M. El-Kady and A. Farag. 2005. Serological studies on the relationships between some Egyptian clover insect pests and their predators. Egypt J. Agric. Res., 83 (3): 873-890.

4. Brown, W.L. J. R., T.E. Eisner and R.H. Whittaker. 1970. Allomones and kairomones : Transspecific chemical messengers. Bioscience 20, 21-22.

5. CoHort Software. 2004. Co. Stat. www. Co Hort Com. Monterey, California, U.S.A.

6. El-Kady, E.A. , M. S. Hassan and A.A. Attia. 1970. Studies on the life - cycle of Hyalopterus pruni (Geoffroy), in Egypt . Bull. Soc. Ent. Egypt 54: 579-582.

7. El-Maghraby, M.M.A. 1993. Seasonal abundance of the cruciferous aphid Brevicoryne brassicae L. (Homoptera , Aphididae) in relation to the primary and hyperparasitoids on cauliflower in Zagazig Region, Egypt . J. Agric. Res. 20 (5): 1627-1639.

8. El-Maghraby, M.M.A., M.M.El-Zohairy, Aziza, M. El-Gantiry and Sh. A.M.Ali. 2008. Biological characteristics and predation efficacy of Chrysoperla carnea (Stephens) on certain preys associated with different host plants. Egypt. J. of Appl. Sci., 23 (10A) : 374-387. 
9. Ferrell, J. A. and M.W. Stufkens. 1990. The impact of Aphidius rhopalosiph (Hymenoptera: Aphidiidae) on population of the rose grain aphid , Metopolophium dirhodium (Homoptera: Aphididae) on cereals in cankrbury. NewZeland. Bull. Entomol. Res. 80: 377-383.

10. Ibrahim , A.M.A. 1987. Studies on Aphidophagous parasitoids with special reference to Aphidius uzbekistanicus (Luz) (Hymenoptera, Aphidiidae). Ph. D. Thesis, Faculty of Agric. Cairo Univ., pp. 202.

11. Ibrahim , A.M.A. and A.I. Afifi. 1994. Aphidius colemani Viereck and Aphidius picipes (Nees) as parasitoids on the Mealy aphid, Hyalopterus pruni (Geoffroy) on peach in Egypt. J. Biol. Pest Control 4 (1): 45-56.

12. Ismail, I.I., S. El-Nagar and A.A. Attia. 1986. The aphid fauna of fruit trees in Egypt. African Journal of Agricultural Sciences 13 (1+2) : 1-7.

13. Ismail, I.I.I., S. El-Nagar and A.A. Attia. 1991. The aphid fauna of fruit trees in Egypt J. Agric. Res. , 69 (1): 235-243.

14. Saleh, A.A.A. 2000. Ecological and biological studies on certain aphid, parasites at Mansoura district. M.Sc. Thesis, Fac. of Agric., Mansoura Univ., pp. 85.

15. Saleh, A.A.A. 2004. Mass production and field application of some aphid natural enemies. Ph. D. Thesis, Fac. of Agric., Mansoura Univ., pp. 161.

16. Saleh, A.A.A. 2008. Ecological and biological studies of Diaeretiella rapae (M'Intosh) (Hymenoptera: Aphidiidae), the parasitoid of some aphid species in Egypt . Egyptian Journal of Biological Pest Control, 18 (1): 33-38.

17. Stary, P. 1970. Biology of aphid parasites (Hymenoptera : Aphidiidae) with respect of integrated control. Series Entomol, Vol. 6 Dr. W. Junk, The Hague, 643pp. 
Hyalopterus pruni الأعداء الحيوية التى تهاجم من البرقوق الدقيقى

(Geoffroy)

فى بستان الخوخ بمحافظة الإسماعيلية - مصر

أحمد أمين أحمد صالح' ، شحته على محمد على' ، نادية الحسينى محمد'

ا ـ قسم بحوث المكافحة البيولوجية ، معهد بحوث وقاية النباتات - مركز البحوث الزراعية -

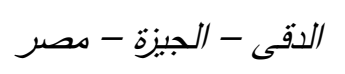

r ـ قسم بحوث الحشرات الثاقبة الماصنة ، معهد بحوث وقاية النباتات - مركز البحوث الزراعبة

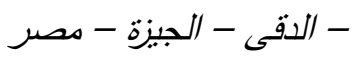

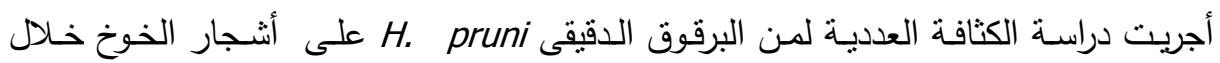

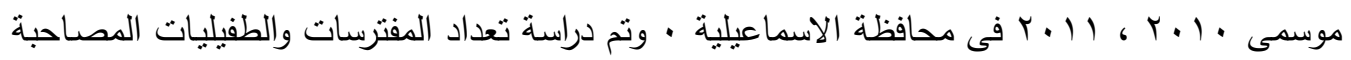

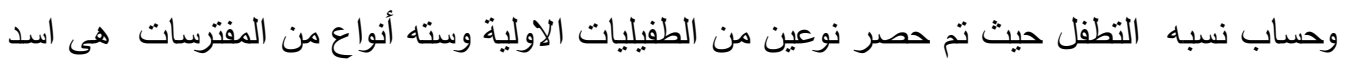

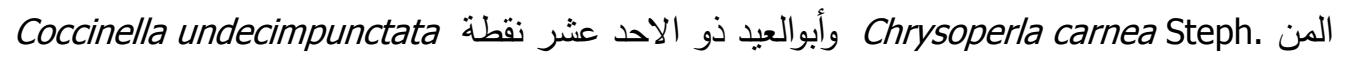

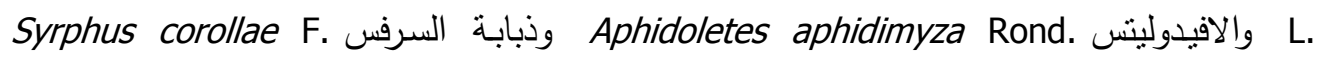
وأبوالعيد السمنى Cydonia vicinia nilotica Muls وأبوالعيد الاسكمنس Scymnus interruptus ودئس Aphidius colemani Viereck and A picipes (Nees) بينما الطفيليان كانا Goeze

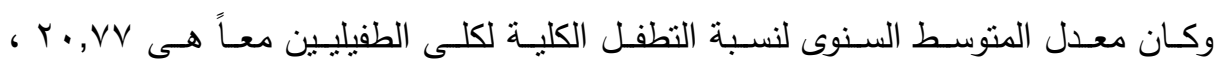

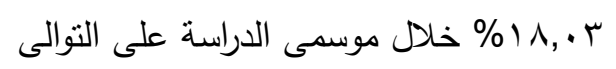

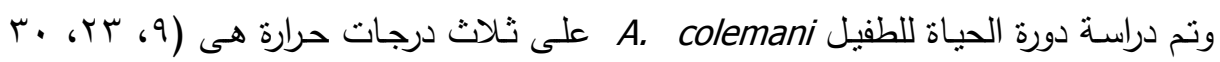

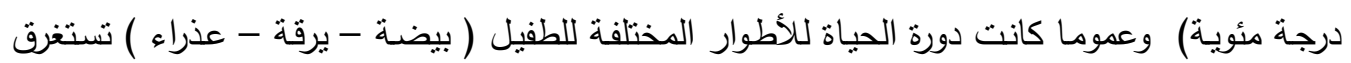

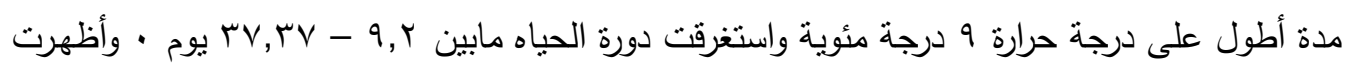

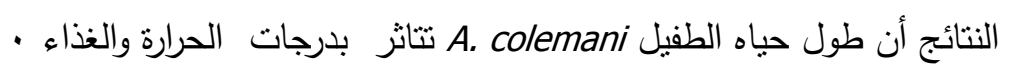

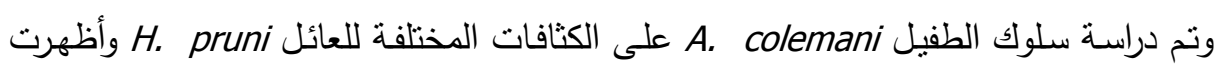

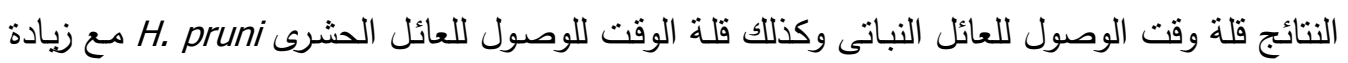

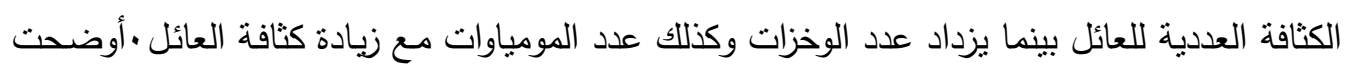

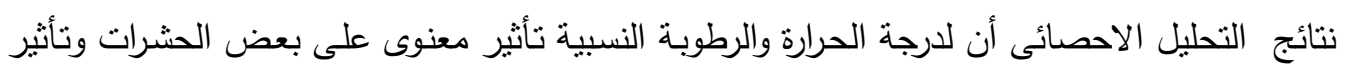
غير معنوى على البعض الاخر ل 